\author{
T.V. ANDRIANOVA \\ M.G. Kholodny Institute of Botany, National Academy of Sciences of Ukraine \\ 2 Tereshchenkivska Str., Kyiv 01601 Ukraine \\ tand@darwin.relc.com
}

\title{
NEW DATA ON SPECIES OF DISCOSIA, ROBILLARDA AND TRUNCATELLA (XYLARIALES, ASCOMYCOTA) IN UKRAINE
}

K e y w o $r d s$ : anamorph, appendage-bearing conidia, Xylariales, Amphisphaeriaceae

\begin{abstract}
Rare anamorphic fungi Discosia circaeae Lobik on Circaea intermedia Ehrh. and Robillarda vitis Prill. et Delacr. on Parthenocissus quinquefolia (L.) Planch. are first reported from Ukraine. A new host plant $P$. quinquefolia is first registered for the fungus Truncatella angustata (Pers.) Hughes. Detailed characters of morphology, geographic distribution, notes on their taxonomy and illustrations are provided for all studied fungi.
\end{abstract}

One of the manifestations of rich diversity in fungal spore morphology among Ascomycotina is characterized by formation of ancillary structures, recognized as «appendages». More than 150 genera of anamorphic coelomycetes produce appendage-bearing conidia and provide for investigators a workable approach to identification of these fungi (Nag Raj, 1993). Such morphological structures are most common for fungi adapted to specific ecological environment as fresh and salt water, dung, and to a lesser extent to terrestrial habitats. Among them are saprobes and hemibiotrophs which conidia are released passively under moist conditions.

During study of plant-associated anamorphic fungi in Ukraine, rare coelomycetes with appendage-bearing conidia were collected on living leaves of Circaea intermedia Ehrh. and Parthenocissus quinquefolia (L.) Planch. The anamorphic fungi were identified as Discosia circaeae Lobik, Robillarda vitis Prill. et Delacr., and are first reported from Ukraine. Another collected species is Truncatella angustata (Pers.) Hughes, quite rare anamorph on a new host plant. Discussed below are characters of their morphology and geographic distribution, notes on their taxonomy and illustrations.

1. Discosia circaeae Lobik, Болезни Растений [Morbi Plantarum], Leningrad 17 (3-4): 185.1927 (1928). Fig. 1.

Leaf spots first orbicular, about 1-2 mm diam., grayish brown; later orbicular or irregular, scattered, 3-6 mm

(C) T.V. ANDRIANOVA, 2014 across, pale brown, with a centre pale yellowish brown, parchment, bearing conidiomata, and with a brown distinct narrow margin, slightly elevated and sharply delimited from other leaf tissues; lesions cover leaf surface between veins; leaf tending to perforate in the centre of lesions. Conidiomata eustromastic to subpycnidial, on both surfaces of leaf, scattered, dark brown, circular when viewed from above, reniform to subglobose, flattened, superficial or subepidermal, brown, 150$220 \mathrm{~mm}$ diam., 30-40 mm depth, unilocular; basal wall 10-20 mm diam., surrounded by one layer of dark brown cells; when absent, dehiscence by break down of upper wall. Conidiophores reduced to conidiogenous cells. Conidiogenous cells colourless, ampulliform to doliiform, $3-4(-8) \times 1.5-2.0 \mu \mathrm{m}$, discrete or integrated, smooth, arising on hyphal layer of the conidiomatal cavity, holoblastic, with one apical proliferation, sometimes with a few repeated sequence of percurrent enteroblastic proliferations (annellations), followed by a replacement wall-building apex, with each conidium delimited at a point more distal than the previous, and with unthickened scars where conidia have seceded. Conidia with yellowish or greenish tint, central conidial cells more intensively coloured, cylindric to oblongelliptical, straight or curved, sometimes slightly flexuous, $15-20 \times 2.5-3.2 \mu \mathrm{m}$, smooth, rounded at the apex, tapered and truncate at the base, 3-septate, thin-walled, in mucoid sheath; cells about equal or unequal, median cells cylindrical, adjacent to the apex middle cell the same size or shorter than middle cell closer to base, 4.0-4.5 $\mu \mathrm{m}$ long and 4.5-7.0 $\mu \mathrm{m}$ long, respectively; bearing two excentric, unbranched, flexuous, tubular appendages, showing protoplasmic continuity with conidial cells, $4.5-8.0 \times 0.3-0.5 \mu \mathrm{m}$, joined on one line along inside of conidial curve, smooth, attenuated towards apex; apical appendage joined nearby to apical septa, basal appendage joint $1.0-1.5 \mu \mathrm{m}$ next to the base of conidium; mean conidium body length to width ratio $6.1: 1$. 

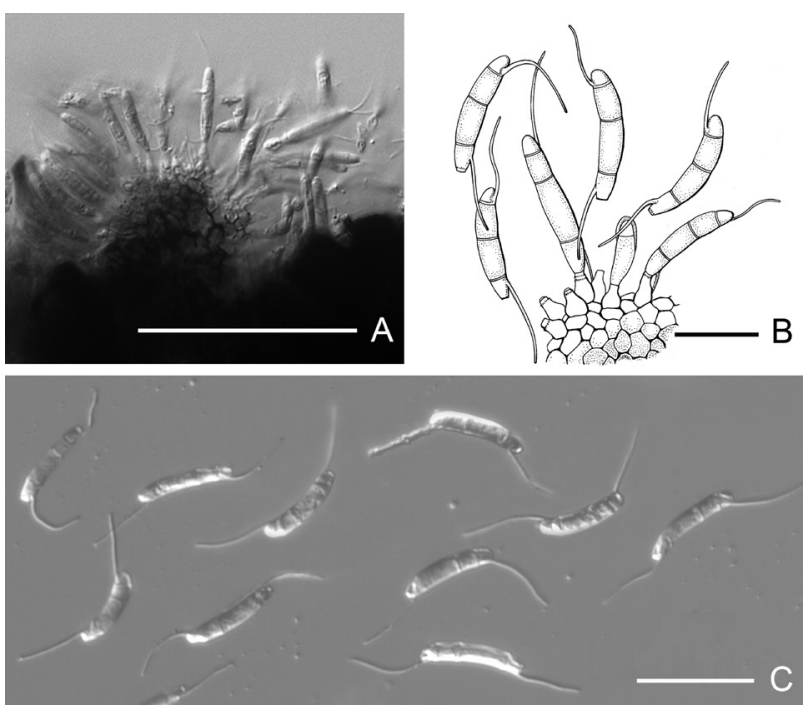

Fig. 1. Discosia circaeae Lobik. A. Transverse section of conidioma showing small conidiogenous cells and conidia. Scale bar $=50 \mu \mathrm{m}$. B. Conidiogenous cells and conidia. Scale bar $=10 \mu \mathrm{m}$. C. Variety of conidia with appendages. Scale bar $=20 \mu \mathrm{m}$.

Substrata. On living and withering leaves of Circaea intermedia Ehrh. (Onagraceae).

Locality. Mixed forest of Fagus sylvatica and Quercus robur, Stavchanske forestry, Roztochchya Nature Reserve (49 57'70" N, 2365'44" E), Yavoriv district, Lviv oblast, Ukraine, 12.08.1989. New for Ukraine.

Geographical distribution. Europe: Russia (Stavropol' krai), Ukraine.

This fungus is a hemibiotroph that causes leaf spots of Circaea and only rarely can invade young upper leaves. The disease development ranges from weak to severe on different plants and it can cause earlier leaves fading and dying. The fungus is known from ecotopes with humid climatic conditions. First, Discosia circaeae was found and described on Circaea lutetiana L. in woods of the Caucasus Mountains (mountain Zheleznaya) near Pyatigorsk, Russia in July 1923 (Лобик, 1928). Our second collection of the fungus was done in mixed beech forests of Lviv oblast, Ukraine, during rather rainy vegetation season of 1989. Quite possible, D. circaeae has more wide distribution.

General morphological similarity of macrostructures among most species of the genus Discosia Lib., disregard of conidium and appendage proportions are the reasons of sometimes inaccurate information about these fungi geographic range. Modern molecular studies of the genus resulted in separation of the new genus Immersidiscosia Kaz. Tanaka, Okane et Hosoya and showed that species delineation remains a problem in Discosia (Tanaka et al., 2011). One of the true Discosia species, D. artocreas (Tode) Fr., is a very common plurivorous saprobe described on Fagus sp. and occurring on a wide range of plants that number about 226 species (Andrianova, Minter, 2012). Discosia artocreas is well-known in Ukraine and recently was revealed by the author on the new host plants Iris sibirica L. (Sumy oblast, 20.09.2008) and Parthenocissus quinquifolia (Kyiv oblast, 30.08.2009). It was suggested that many specimens currently disposed as $D$. artocreas could, in fact, represent cryptic species (Tanaka et al., 2011). First of all, the reports on D. circaeae findings seem to be hidden under the name of $D$. artocreas in collections that were published without indication of associated orgaisms. The fungus is supposed to be prognostic to Bulgaria (Ванев и др., 1997) and, according to its current known range, it can occur in Armenia, Georgia and Turkey.

Discosia circaeae was accepted as a separate species by Subramanian and Chandra-Reddy (1974) in their extensive studies of the genus Discosia which included the examination of type material and numerous specimens collected worldwide. The monographer of anamorphic fungi with appendaged conidia, Nag Raj (1993), just indicated that the material of $D$. circaeae species was not examined in his study. Later Vanev (Vanev, 1991; Ванев и др., 1997) analyzed about 70 known species of Discosia and accepted only 31 species, including $D$. circaeae. The fungus was placed in section Discosia Vanev that incorporated species with distal appendages and unequal size of conidium cells, when the longest cell is the third one from the apical part of the conidium. The type of this section is $D$. artocreas. In fact, undertaken study has revealed that in $D$. circaeae the third cell is not significantly longer than the others. Presence of about equal median cells suggests reallocation of the species $D$. circaeae to section Laurina Vanev. Other important differences which distinguish this species from $D$. artocreas are much smaller mean conidium body length to width ratio and location of the appendage and apical conidial cell junction point close to the upper septum of conidium. In $D$. artocreas, this appendage arises from almost the apex of the subtending cell (Nag Raj, 1993; Andrianova, Minter, 2012). Those characters place $D$. circaeae closer to $D$. pleurochaeta Durieu et Mont. (Ванев и др., 1997) and D. brasiliensis Nag Raj (Nag Raj, 1993) and separate this species from D. artocreas. Teleomorphs of above discussed Discosia species are not known, though some other species of the genus revealed to be connected with new genus Adisciso Kaz. Tanaka, Okane et Hosoya (Tanaka et al., 2011), placed in the ascomycete family Amphisphaeriaceae (Xylariales). 
2. Robillarda vitis Prill. et Delacr., Bulletin de la Société Mycologique de France 5(4): 124. (1889) 1890. Figs. 2, 3.

Leaf spots first angular or irregular, about $1-3 \mathrm{~mm}$ across, brown, with a centre pale brown, scattered between veins, sharply delimited from other leaf tissues; old lesions irregular, dark brown, slightly elevated and distinct, up to $4 \mathrm{~mm}$ across, bearing conidiomata, with broad reddish halo tending to spread along the leaf surface. Conidiomata subpycnidial or pycnidial, on upper surface of leaf, scattered, discrete, circular when viewed from above, globose to subglobose, ostiolate or later broadly opened, immersed, subepidermal, erumpent, light brown to brown, 70-100 mm diam., unilocular; with a wall $12-15 \mu \mathrm{m}$ thick, composed of 6-7 layers of small textura angularis being pale brown internally and more coloured in the outer parts, coarse and elongated cells of $1-2$ outer layers moderately thickwalled. Ostiole circular, central, 20-25 $\mu \mathrm{m}$ diam. or wide opened in actively sporulating conidiomata, surrounded by brown, thick-walled cells. Conidiophores reduced to conidiogenous cells lining the cavity of the conidioma. Conidiogenous cells colourless or with greenish tint, ampulliform to flat-globose, 4-5.× $3-5 \mu \mathrm{m}$, discrete, smooth, arising from the cells lining the conidiomatal cavity, holoblastic, each producing only one conidium or sometimes with a limited number of sympodial proliferations, with occasionally two conidia simultaneously attached to the conidiogenous

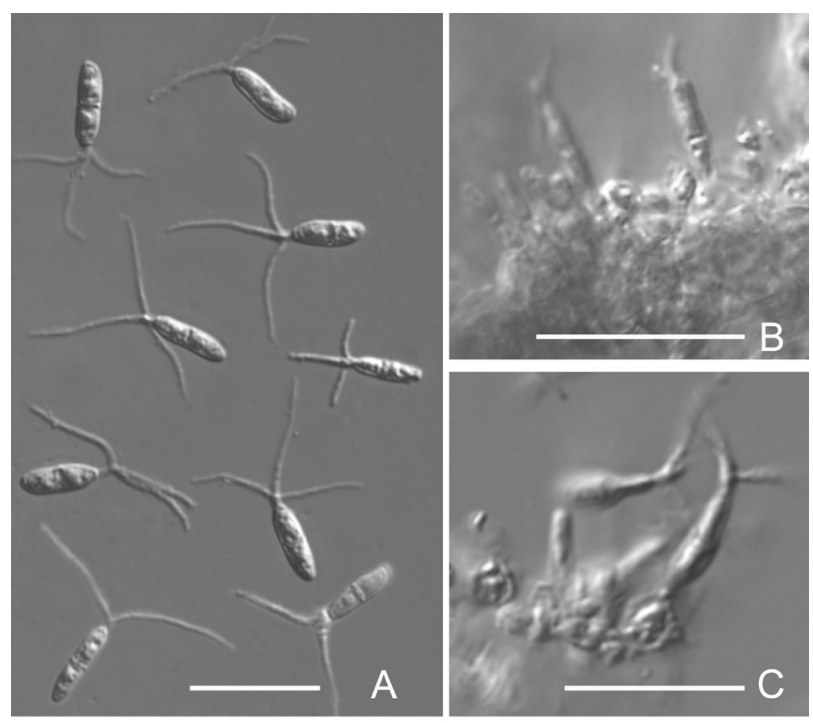

Fig. 2. Robillarda vitis Prill. et Delacr. A. Light coloured conidia with appendages. B. Cross-section through conidiomatal wall showing conidiogenous layer and juvenile appendaged conidia. C. Conidiogenous cells producing conidia. Scale bars $=20 \mu \mathrm{m}$.

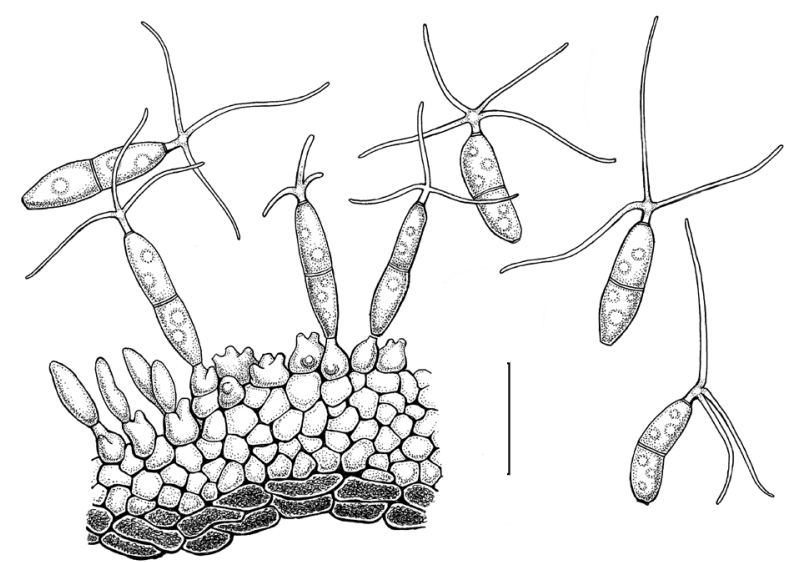

Fig.3. Robillarda vitis Prill. et Delacr. View of conidiogenous cells and conidia with appendages. Scale bar $=10 \mu \mathrm{m}$.

cell, secessional scars unthickened. Conidia fusiform to oblong ellipsoid, straight or somewhat curved, greenish olive, (10-) 11-13 × (3.3-) 3.5-4.0 $\mu \mathrm{m}, 1$-septate, slightly narrower at the septum, smooth; apical conidial cell bearing colourless, $2.0-2.5 \mu \mathrm{m}$, cellular structure with a crest of 3-4 unbranched, colorless, apical appendages, $7.0-13.5(-16.6) \times 1.0-1.5 \mu \mathrm{m}$, flexuous, smooth, tubular, having protoplasmic continuity with the subtending cell, attenuated toward the apex, always present; mean conidium body length to width ratio $3.2: 1$.

Substrata. On living and fading leaves of Parthenocissus quinquefolia (L.) Planch. (Vitaceae).

Locality. Forest of Pinus sylvestris, near Pliuty settlement $\left(50^{\circ} 12^{\prime} 39^{\prime}\right.$ N, $30^{\circ} 39^{\prime} 15^{\prime}$ E) , Obukhiv district, Kyiv oblast, Ukraine, 23.08.2009. New for Ukraine.

Geographical distribution. Europe: France, Ukraine.

There are 35 names referred to Robillarda Sacc., 13 of which are well-defined species of this genus (Index Fungorum, 2013), about 15 other names are still without critical reappraisal, though used as species names in the genus Robillarda. Studied $R$. vitis is one of unexamined species. The fungus was first collected on leaves of Vitis vinifera L. in Gironde, France. It occurred on leaf lesions with red margins, formed immersed, pycnidial conidiomata that produced olivaceous, fusoid conidia, $10-11 \times 4 \mu \mathrm{m}$, with 3 apical appendages, $8-15 \times 1 \mu \mathrm{m}$ (Prillieux, Delacroix, 1890). The type of Robillarda appendage structures were shown to consist of a short, nucleate, club-like cellular formation with several unbranched, tubular extentions, also each nucleate (Punithalingam, 1989). According original description the species $R$. vitis has some morphological features that partly resemble $R$. sessilis (Sacc.) Sacc., known from dead branches, bark, leaves, seeds and acorns of different plants, and $R$. rhizophorae Kohm., associ- 
ated with roots of Rhizophora. The fungus $R$. sessilis is rarely detected in a few countries of Africa, America and Eurasia; it was recently registered in nature from Lithuania (Treigiené, Grigaliūnaité, 2007) and Belarus (Yurchenko, Belomesyatseva, 2010). According the results of Nag Raj (1993) monographic study, R. sessilis conidia are of various shades of brown and about $3 \mu \mathrm{m}$ in width, tending to have mean conidium body length to width ratio $4: 1$. Our study of Belarussian material of $R$. sessilis (Yurchenko, Belomesyatseva, 2010), due to kind permission of the authors, supported the view that $R$. vitis differs from the latter fungus by small-size conidioma, more globose conidiogenous cells and lesser conidial length to width ratio. The position of the genus Robillarda is not defined, the only species of this genus, $R$. sessilis, has undergone the molecular analysis of the LSU, SSU and ITS nrDNA and clustered with representatives of the ascomycete family Amphisphaeriaceae (Xylariales) without affinity with any genus in it (Rungjindamai et al., 2012).

\section{Truncatella angustata (Pers.) Hughes, Canadian} Journal of Botany 36(6): 822. 1958. Fig. 4.

Leaf spots on old living and withering leaves, lesions indistinct, few on a leaf, without clear outlines, indeterminate, minute, $2-3 \mathrm{~mm}$ across, starting as a change of tissue colour from greyish green to pale yellowish brown; with no obvious halo; plant tissues later becoming dry. Conidiomata scattered, acervular, at first subepidermal, later erumpent, circular when viewed from above, lenticular in vertical transverse section, 130-220 $\times$ $40-60 \mu \mathrm{m}$, unilocular, glabrous, brown; opening by a longitudinal split in the overlying host tissue; basal wall $25-30 \mu \mathrm{m}$ thick, composed of small textura angularis, cells thick-walled, varying from brown in the outer parts to colourless internally. Conidiophores lining the cavity of the conidioma, erect, sparsely septate, unbranched or irregularly branched, colourless, smooth, $10-17(-20) \times$ 1.7-2.0 $\mu \mathrm{m}$, covered in mucus. Conidiogenous cells terminal, discrete or integrated, lageniform to cylindrical, 7-13 $\times 1.7-2.0 \mu \mathrm{m}$, colourless, thin-walled, smooth; holoblastic, with repeated percurrent enteroblastic proliferations by replacement wall-building apices, each conidium delimited at a point distal to the previous, resulting in annellations; secession schizolytic. Conidia fusiform, slightly curved, 3-septate, (13.5-) 15.0-19.0 $\times(5.5-) 6.0-7.5 \mu \mathrm{m}$, thick-walled, bearing appendages; basal cell obconic, $2-3 \mu \mathrm{m}$ long, with a truncate base, colourless, smooth, narrower than the central cells; central cells both doliiform, with unequal length

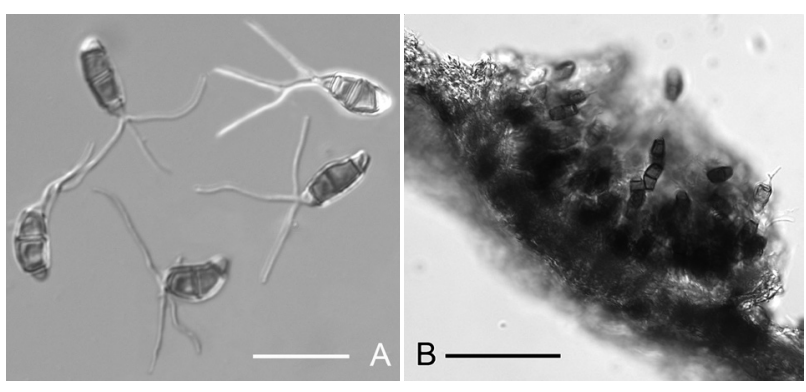

Fig. 4. Truncatella angustata (Pers.) Hughes. A. Variety of conidia with appendages. Scale bar $=20 \mu \mathrm{m}$. B. Transverse section of conidioma with conidia. Scale bar $=50 \mu \mathrm{m}$.

of cell side board, brown, without constrictions at the septa, together 10-12 $\mu \mathrm{m}$ long; apical cell conical, colourless, smooth, 1.0-1.5 $\times 1.5-2.5 \mu \mathrm{m}$; appendages on the apical cell arising in an apical crest of $2-3$, tubular extensions having protoplasmic continuity with the subtending cell, sometimes irregularly or dichotomously branched, filiform, flexuous, $13-25 \cdot \times 1.0 \mu \mathrm{m}$, smooth; mean conidium length to width ratio $2.7: 1$.

Substrata. On withering old leaves of Parthenocissus quinquefolia (L.) Planch. (Vitaceae). New host plant.

Locality. Planting, near Kozyn settlement (50 $12^{\circ} 15^{\prime \prime}$ N, 30³9'57” E), Obukhiv district, Kyiv oblast, Ukraine, 30.08.2009.

Geographical distribution. Asia: Armenia, India, Iran, Japan, Kazakhstan; Australasia: Australia, New Zealand; Europe: Austria, Belgium, Czech Republic, Denmark, Finland, France, Germany, Greece, Ireland, Italy, Lithuania, Norway, Poland, Portugal, Russia, Spain, Sweden, Switzerland, Ukraine, United Kingdom; Noth America: Canada, USA; South America: Brazil, Chili, Ecuador.

The anamorph T. angustata was registered in Ukraine on different trees of the genera Acer, Carpinus, Fagus, Platanus and Robinia since 1925. The fungus is widely distributed all over the world and known on many host plants from various families (Nag Raj, 1993). It colonises plant substrates and produces conidiomata on leaves, stems, twigs and fruits. Truncatella angustata was isolated as a fungal endophite from different cultivated plants and from soils. Most recent investigations report on T. angustata as an agent that is associated with serious diseases of Olea, Rosa, Vaccinium and Vitis (Espinoza et al., 2008; Eken et al., 2009; Arzanlou et al., 2012, 2013). Thus, collection of the fungus on a new host plant from the family Vitaceae, Parthenocissus quinquefolia, may indicate its possible colonization of grapevine in Ukraine as well. 
Species concept and nomenclature of $T$. angustata are problematic due to variability of the representatives of anamorphic pestalotioid genera. Accoring Nag Raj (1993), conidia of Truncatella Steyaert species are characterized by lacking basal and branched apical appendages, concolours median cells; unlike Pestalotiopsis Steyaert species that differ by presence of basal appendage and apical crest of conidial unbranched appendages, versicoloured median cells. It is possible to distinguish $T$. angustata from rather similar morphologically P. stevensonii (Peck) Nag Raj by the complete absence of a basal appendage. Sequence data of ITS-rDNA region have demonstrated that $T$. angustata is rather allied but not identical with some species of the genera Seimatosporium Corda and Pestalotiopsis and clustered with representatives of Xylariales (Tanaka et al., 2011; Arzanlou et al., 2012). The teleomorph of T. angustata is reported by the Index Fungorum (2013) to be a member of the genus Broomella Sacc. (Amphisphaeriaceae, Xylariales). The presumptive teleomorph Broomella acuta Shoemaker et E. Müll. (Shoemaker, Müller, 1963) was proposed due to the same time collection with Pestalotia truncata Lév. on Clematis flammula L., one of possible synonymous anamorphs of $T$. angustata, that needs further study.

\section{REFERENCES}

Andrianova T.V., Minter D.W. Discosia artocreas. IMI Descriptions of Fungi and Bacteria. CAB International, 2012. - Set 194, N 1933. - P. 1-7.

Arzanlou M., Narmani A., Moshari S., Khodaei S., Babai-Ahari A. Truncatella angustata associated with grapevine trunk disease in northern Iran // Archives of Phytopathology and Plant Protection. - 2013. - 46(10). - P. 1168-1181.

Arzanlou M., Torbati M., Jafary H. Fruit rot of olive (Olea europaea) caused by Truncatella angustata // Plant Pathology and Quarantine. - 2012. - 2(2). - P. 117-123.

Eken C.A., Spanbayev A.B., Tulegenova Z., Abiev S. First report of Truncatella angustata causing leaf spot on Rosa canina in Kazakhstan // Australasian Plant Disease Notes. - 2009. 4(1). - P. 44-45.

Espinoza J.G., Briceño E.X., Keith L.M., Latorre B.A. Canker and twig dieback of blueberry caused by Pestalotiopsis spp. and a Truncatella sp. in Chile // Plant Dis. - 2008. 92(10). - P. 1407-1414.

Index Fungorum. Robillarda, Truncatella, 2013 (http://www. indexfungorum. org/names/Names.asp)

Nag Raj T.R. Coelomycetous anamorphs with appendagebearing conidia. - Waterloo, Ontario: Mycologue Publications, 1993. - $1101 \mathrm{pp}$.

Prillieux E.E., Delacroix E.G. Quelques champignons parasites nouveaux ou peu connus // Bull. Soc. Mycol. de France. (1889) 1890. - 5(4). - P. 124-127.

Punithalingam E. The significance of nucleate conidial appendages in Coelomycetes // Studies in Mycology. 1989. - 31. - P. 113-121.

Rungjindamai N., Sakayaroj J., Somrithipol S., Plaingam N., Jones E.B.G. Phylogeny of the appendaged coelomycete genera: Pseudorobillarda, Robillarda, and Xepiculopsis based on nuclear ribosomal DNA sequences // Cryptogamie. 2012. - 33(3). - P. 319-332.

Shoemaker R.A., Müller E. Generic correlations and concepts: Broomella and Pestalotia // Can. J. Bot. - 1963. - 41(8). P. 1235-1244.

Subramanian C.V., Chandra-Reddy K.R. The genus Discosia. I. Taxonomy // Kavaka. - 1974. - 2. - P. 57-89.

Tanaka K., Endo M., Hirayama K., Okane I., Hosoya T., Sato T. Phylogeny of Discosia and Seimatosporium, and introduction of Adisciso and Immersidiscosia genera nova // Persoonia. 2011. - 26. - P. 85-98.

Treigiené A., Grigaliūnaité $B$. Nauji duomenys apie anamorfinius grybus Lietuvoje. Robillarda ir Pseudorobillarda gentys // Botanica Lithuanica. - 2007. - 13(1). - P. 61-63.

Vanev S.G. Species conception and sections delimitation of genus Discosia // Mycotaxon. - 1991. - 41(2). - P. 387396.

Yurchenko E., Belomesyatseva D. Robillarda sessilis, a rare coelomycete isolated from Scots pine seedlings // Acta Mycol. - 2010. - 45, 1. - P. 27-32.

Ванев С., Самева Е., Бакалова Г. Ordo Sphaeropsidales. Гъбите в България. - София: Пенсофт, 1997. - 3. - 335 pp.

Лобик А.И. Материалы к микологической флоре Терского округа // Болезни растений. - 1927 (1928). - 17, 3-4. - C. 157-208.

Recommended for publication

V.P. Heluta

Submitted 07.05.2014

\section{T.В. Андріанова}

Інститут ботаніки імені М.Г. Холодного НАН України, м. Київ

\section{НОВІ ДАНІ ШОДО ВИДІВ DISCOSIA, ROBILLARDA ТА TRUNCATELLA (XYLARIALES, ASCOMYCOTA) В УКРАЇНI}

Повідомляється про першу в Україні знахідку рідкісних анаморфних грибів Discosia circaeae Lobik на Circaea intermedia Ehrh. та Robillarda vitis Prill. et Delacr. на Parthenocissus quinquefolia (L.) Planch. Нова живильна рослина $P$. quinquefolia вперше зареєстрована для гриба Truncatella angustata (Pers.) Hughes. Представлені детальні описи морфологічних ознак, географічне розповсюдження, нотатки щодо таксономії та ілюстрації всіх вивчених видів.

Ключ и в і слов в: анаморфа, конідії відростками, Xylariales, Amphisphaeriaceae.

\section{T.В. Андрианова}

Институт ботаники иммени Н.Г. Холодного НАН Украины, г. Киев

\section{НОВЫЕ ДАННЫЕ О ВИДАХ DISCOSIA, ROBILLARDA И} TRUNCATELLA (XYLARIALES, ASCOMYCOTA) В УКРАИНЕ

Сообщается о первой в Украине находке редких анаморфных грибов Discosia circaeae Lobik на Circaea intermedia Ehrh. и Robillarda vitis Prill. et Delacr. на Parthenocissus quinquefolia (L.) Planch. Новое питающее растение $P$. quinquefolia впервые зарегестрировано для гриба Truncatella angustata (Pers.) Hughes. Представлены детальные описания морфологических признаков, географичнеское распространение, заметки по таксономии и иллюстрации всех изученных видов.

Ключ ев в е слов в: анаморфа, конидии с отростками, Xylariales, Amphisphaeriaceae. 